\title{
Does Firms' Social Responsibility Counteract Some Critical Effects of Labor Market Flexibility?
}

\author{
Nadia Oliva ${ }^{1} \&$ Andrea Pacella ${ }^{2}$ \\ ${ }^{1}$ University "Giustino Fortunato", Benevento, Italy \\ ${ }^{2}$ University of Catania, Catania, Italy \\ Correspodance: Nadia Oliva, University Giustino Fortunato, Viale Delcogliano, 12 Benevento, Italy. Tel: \\ 39-328-465-0868. E-mail: n.oliva@unifortunato.eu
}

\author{
Received: January 11, 2016 Accepted: February 3, 2016 Online Published: February 25, 2016 \\ doi:10.5539/jms.v6n1p109 URL: http://dx.doi.org/10.5539/jms.v6n1p109
}

\begin{abstract}
The aim of this paper is twofold. First, it will be argued that the flexibility in labour contract duration can be ineffective in increasing productivity, profits and employment when workers test a high state of uncertainty. Second, it will be shown that these effects can be reduced when firms put into effect a system of social responsibility. What emerges is that while flexibility produces unstable collaborative behavioural codes between employers and employees that damage both, the firms' social responsibility contributes to spread a spirit of shared values and personal gratifications amongst workers that reduce this instability and generate positive economic performances.
\end{abstract}

Keywords: firms' social responsibility, flexibility of labor contract duration, productivity, profits, employment

\section{Introduction}

The labour market is generally understood as a 'place' in which employees and employers meet in order to bargain the quantity/quality of work with wage and achieve a profitable exchange. It stands on the principle of economic evaluation of wants and on the mechanism of market clearing according to which price flexibility allows individual wants to become collectively compatible. Moreover, a perfect competitive labour market works efficiently if employers and employees have the same bargaining power, if wages and other components of the labour relationship are flexible and if the bargaining is free from any external interferences.

An important feature of this framework is that employment increases if flexibility increases. The rationale is that, the higher the flexibility the lower the constraints to the demand for labour and labour supply. Moreover, in the absence of external interferences, unemployment becomes essentially voluntary being the outcome of a free and conscious individual choice not to accept the market conditions (Note 1). Unfortunately, however, the labour market is subject to several micro and macroeconomic failures that hamper the achieving of first best solutions and, among the others, the asymmetric information and the involuntary unemployment play a significant role (Note 2). In this context, flexibility does not necessary increase employment and other economic fundamentals such as productivity and income.

At the same time firms are constantly invited to be sensitive to crucial social issues - such as poverty, environment, sustainability, transparency, respect of human rights and so on - and to create a socially responsible system in the belief that the firm's social responsibility is both fair and advantageous for the community (Note 3).

The categories of flexibility of the labour market and the social responsibility of firms are however treated separately despite being strictly connected on a practical and theoretical level. On a practical level, indeed, if the flexibility of labour markets implies the weakening of the bargaining power of workers, wages can reduce and dismissals can increase. If these effects are deep and persistent new social issues will emerge, such as poverty and social exclusion to name a few. These issues, in turn, become critical for the socially responsible firms, so the higher the inefficiency of flexibility, the higher the need for intervention of (socially responsible) firms. On a theoretical level, then, when firms are widely sensitive to the above mentioned social issues, they can create autonomously a trustworthy system for workers, obtaining an increase of productivity and income on one hand, and contributing to restrain social criticalities on the other. 
The detailed aim of this paper is twofold. First, it will be argued that flexibility, in particular in the labour contract duration, can be ineffective in increasing productivity, profits and employment when workers test a high state of uncertainty connected to the reduction of their bargaining power. Second, it will be shown that these effects can be reduced when firms put in place a system of social responsibility toward workers. What emerges is that while flexibility produces unstable cooperative behavioural codes between employers and employees that damage both, the firms' social responsibility contributes to improve the job quality by spreading shared values and personal gratifications that push workers to increase productivity reducing the instability and generating positive economic performances (Note 4).

On the methodological plane we use a deductive theoretical method resuming the recent Italian Post Keynesian critical approach to the flexibility of the labor market and enlarging the discussion by the graft of moral codes in the behavioral functions of agents.

The paper is organized as follows: Section 2 discusses the main economic and institutional traits of firms' social responsibility and its impact on the job quality. Section 3, instead, discusses the effects of flexibility of labour contract duration on the economic performances. Section 4 concludes.

\section{Ethical Codes, Firms' Social Responsibility and Job Quality}

The concept of firms' social responsibility is strictly connected to the ethics of responsibility, where responsibility acts as individual and social commitment to take charge of one's own actions and their consequences (Note 5). Amongst the others, Max Weber, Hans Jonas and Jacques Derrida treated the subject in a detailed way. With reference, in particular, to the position of Weber (1918/1919), Sung Ho (2012) so writes:

"According to the ethic of responsibility [...] an action is given meaning only as a cause of an effect, that is, only in terms of its causal relationship to the empirical world. The virtue lies in an objective understanding of the possible causal effect of an action and the calculated reorientation of the elements of an action in such a way as to achieve a desired consequence".

The values of actions, indeed, depend on their objective consequences. Note that consequences are not evaluated by emotional criteria but by rational ones (Note 6). As Sung Ho (2012) adds,

"An ethical question is thereby reduced to a question of technically correct procedure, and free action consists of choosing the correct means. By emphasizing the causality to which a free agent subscribes, in short, Weber prescribes an ethical integrity between action and consequences".

Despite profit maximization keeps being considered the firm's fundamental goal (Note 7), in the last decades many economists have rediscovered the importance of ethics within firms and values such as honesty, responsibility, transparency and respect of human rights, emphasizing therefore how ethics within one's economic conduct has today become a necessity more than a choice.

Profit and ethics are two concepts that do not clash with one another. It is necessary to go beyond the perception of contrast between economic needs and human progress in order to elaborate an idea of development that joins together the firm's reproduction and growth, employees' satisfaction and fulfillment of social responsibilities (see Sen, 2012). The analysis of the optimizing behavior of firms cannot, therefore, overlook morals, being them an integral part of that same behavior and also being a modulation factor of its outcomes.

The attempt to confine rational behavior within a system of actions finalized to the simple efficient allocation of resources and in an institutional vacuum is not, in fact, able to concretely resolve many of the social or economic issues arising (and not just that), such as, equity, poverty, human and natural resources exploitation, etc.. and this not because of the institutional pressure put on individual freedom, but because of the internalization of behaviors that are 'alien' to the ethical dimension. Social expenses, external diseconomies, diffuse poverty and frequent disasters with loss of human lives, denied workers' rights, uncontrolled loss of jobs, are all illegitimate outcomes of a "techno-nihilist capitalism without rules or controls" (Ricci, 2013, p.41, our translation).

One possibility to critically verify the effectiveness of a firm's actions is to evaluate the effects of interconnections between institutions-firms-workers extending the sense of governance and evaluating the results of responsible behaviors.

Sacconi (1997), for example, considers firms social responsibility (FSR hereafter) as a commitment to comply with a "system of regulations explicated and shared as [...] ethical code". Porter and Kramer (2011), instead, interpret FSR as an advantage, a competitive stimulus that enhances the firm's image on the market, a form of investment rather than a burden or an extra load for firms. By FSR, they add, firms gain transparency, brand 
improvement, creditworthiness, and so on. Moreover FSR increases employees' performances and labor productivity allowing firms to absorb the costs incurred to implement social strategies.

The importance of ethics within enterprises has been recognized not just on a scientific level but also on a political one in many countries. In Europe, for example, in the 2001 Green Book, the European Commission defines FSR as an "integration of the social and ecological issues in the commercial operations and in relationships of the enterprise with the parties involved" (EC, 2001, p.7, our translation) (Note 8). In these terms, then, FSR is intended as a component of its identity. It follows that the resolution of social issues acquires an integrating value that is not in conflict with profit, losing the corrective nature of economic actions generating some sort of negative externality. The European Union, therefore, invites firms to adopt an open governance system, using a deontological code that is able to reconcile the logic of profit with social-environmental balances and identifying, at the same time, a real Chart of Common Values.

FSR is extensively spreading all over the world. In the U.S., for example, the drafting of ethical codes is very widespread and about $85 \%$ of the main firms adopt such tool (see Sacconi, 2000). Japan, instead, is considered the pioneer of FSR since the country has always held a particular sensitivity regarding the social role of firms which are not seen as entities isolated from society and devoted only to the profit maximization. The term social responsibility was used for the first time in 1956, when the association of Japanese entrepreneurs Keizai Doyukai drafted the document titled "Consciousness and Procedure of Enterprises Social Responsibility". The government also created a regulatory framework that facilitated its diffusion. Firms have effectively understood the needs linked to FSR, redefining strategies and firm structure (Lanna, 2009, pp. 103-134). In Italy the ethical codes show the firm's social commitment, while the standards, decided on international level, aim to align firms' choices.

The SA 8000 standard - drawn out by CEPAA (Note 9) and issued in 1997-regulates in particular worker's rights not only inside firm but also outside it for the whole production chain. It supports a formal commitment for the respect of the principles in matter of child labor, compulsory labor, health and safety, freedom of association and collective bargaining right, disciplinary procedures, working hours, payment and human resources managing system.

As previously noted, institutional interventions in matter of FSR are generally not coercive. It follows that FSR can be conceived as a set of endogenous tools aimed at self-regulate and/or co-regulate the economic activity according to its social implications (Note 10). Essentially it is about pinpointing and realizing an ethical code that can be defined 'Constitutional Company Chart' meant as a voluntary self-regulating document illustrating rights, obligations and mission of a socially responsible firm.

Special attention is given to the ethical behavioral standards within the enterprise management for matters concerning work environment, discrimination, wages, child labor, freedom of association, training activities and protection of human rights. All subjects within the company that has adopted an ethical code must absorb and share the values content within this document.

The standard tool for measuring effects and strategies of FSR is the social balance integrated to the balance sheet. It is a non-accounting document reporting the economic, social and environmental performances of the firm. It measures its expectations, the degree of satisfaction and the stakeholders consensus, marking the transition of reporting from the market-only model to the FSR model.

In Italy a specific regulation demanding that firms show their social impact of their activity does not exist. The social balance, indeed, is a voluntary document. In France, instead, the social balance is mandatory from 1977 for firms with more than 300 workers. Note also that the Community Directive no. 51 of 17 July 2003, which modifies the art. 46 of the IV CEE Directive issued on 25 July 1978 regulating the content of the management report, provides for the inclusion of information regarding environment and staff. In 2014 the European Commission releases the amendment to the IV Directive that will have to be enforced within two years in all member States. It states that firms with more than 500 employees and public interest are obliged to provide non-financial information notes in their Annual Reports. While the amendment comes into force, the non-financial information note is included in the social balance that describes the firm profile under an integrated approach, evaluating its contribution to financial prosperity, social cohesion and respect of human rights.

The relation between firm's social responsibility and job quality has been an object of discussion for many years now. In 1999, for example, the ILO implemented the Global Compact as a voluntary initiative promoted by Kofi Annan who, in occasion of the Davos Economic Forum, invited the economic world leaders to subscribe an agreement with the United Nations to work on the most critical aspects of globalization in a logic of cooperation, so as to promote a sustainable economy respecting human and work rights, careful to the protection of environment and decided to fight corruption. Ban Ki-moon stated that "markets can prosper only in healthy 
societies, and societies need healthy markets in order to prosper" (Note 11). The firms adhering to the Global Compact committed to sustain workers protection and their rights to abolish all forms of exploitation and discrimination above all.

Today, firms are forced to operate in competitive, dynamic and evolving environments and markets. In order to face competition it is necessary to work on human resources, who are fundamental to the acquisition of a competitive advantage. It is therefore important to create a trustworthy system between the parts, respecting the needs of employees and increasing their performance. Employees' motivation and satisfaction does not depend exclusively on the wage but also on the trust accorded to them, on the increase of their sense of responsibility and their constant involvement in the productive process.

As Mayo (1945) states labour productivity is strongly affected by psycho-sociological variables such as motivation, job security, group relationships, workplace atmosphere and so on. The impact of psycho-sociological variables on productivity is known as "Hawthorne effect" which describes the tendency of workers to increase productivity when they test a spirit of value sharing and moral satisfaction. It follows that workers cooperate with employers and share firm' institutional aims if they receive moral gratifications, respect, appraisal and career prospects. Workers mainly protected in their guarantees, feel as an integral part of the productive system and, attracted by the choices of management, participate with more commitment to the firms' growth.

It is therefore necessary to carry out the process that some authors, such as Argyris (1957), have defined as "fusion process", through which it is possible, in organizational systems, to satisfy both the personalizing and socializing dimension at the same time. This fusion process is actualized, basically, amongst personal motivations, that push the individual to act in order to appease its needs and those that the enterprise intends to respect in order to reach its goals (Ricci, 2012, p. 149). Argyris and Schon (1995) underline how personal growth combines with an increase in productivity with a consequent benefit for the firm. It is possible to affirm that, in managing workers, firm should promote employees human and professional growth, responding to their expectations, endorsing its talents, interests and abilities, rather than penalize them making them feel frustrated an insecure. Motivating factors get into play here, because motivation is the engine that pushes the individual to apply himself thoroughly at work.

As Maslow (1995) also states individual is motivated to act by the intent to satisfy a series of needs that he/she places within a pyramidal hierarchic structure divided into five categories: Physiological needs, safety needs, social needs, esteem needs and self-actualization needs. The key element for this theory is that the individual feels that the most basic level of needs must be met before she/he will desire the secondary or higher level needs. As a limiting tool of the low quality of job, the security needs are fundamental since the stability of the job, in a cozy and structured environment, an adequate wage, bring workers toward self-actualization. If firms manage to meet the higher needs in the Maslow scale, they will manage to reach their goals in a profitable manner.

For the involvement of human resources to be effective, after the motivational rush and the sharing of goals, it is imperative to monitor the deployment of the goals themselves, meaning their tangible achievement through the planning of actual actions. In this view, it is possible to program enhancing systems such as job evaluation, skill evaluation and remuneration systems such as seniority, job enrichment, job enlargement and stock options.

These are high quality tools in a rewarding system that comes into place when, as needs linked to financial performance quality and to the growth of the degree of responsibility of the subjects involved, it becomes necessary to increase the weight of the variable remuneration on the total payment. The rewarding system, together with the FSR can be important tools to attract and acquire human resources, especially the very talented ones and, subsequently, to keep them, giving them the motivation to stay.

\section{Social Responsibility and Flexibility of Labour Contract}

Employment relationships are subject to regulation in all countries although the intensity of regulation is different from country to country. Moreover the components of the employment relationship that are traditionally regulated are: Entry and exit from the market, wages, hours of work, job security, mobility, education and training (see Saint-Paul, 2000, p.1; Björklund et al., 1985, pp. 64-65; McLaughlin, 1992; Layard \& Nickell, 1997; Gutmann \& Thompson, 1996).

Literature argues that the labour market cannot work in an institutional vacuum since the employment relationship is basically conflictive. For this reason institutions emerge just as "tools for the resolutions of conflicts" (see Costabile, 1998, p. 2) (Note 12) and they take the form of bound and binding behavioural codes. On institutional plan, moreover, the labour market is distinguished between a self-regulated or outside regulated 
labour market. Labour market is self-regulated when regulation is endogenous and it derives from the bargaining or by a 'natural evolution'. On the other hand labour market is outside regulated when regulation is exogenous and it is the outcome of political choices (Note 13).

Although economists do not generally deny the efficacy of regulation as such, a large part of them reject the predominance of outside regulation since it is supposed to compress the free bargaining between parties and the efficient allocations of resources. For this reason flexibility, particularly for wages and labour contract duration, is welcomed. "With wage flexibility, in particular, no (or less) external interference is admitted during wage bargaining over compensation while with flexibility in labour contract duration no (or less) external interference is admitted during the bargaining over duration of contract and firms' freedom to hire and fire workers" (Pacella, 2008, p. 610).

Firms, moreover, generally welcome flexibility of the labour contract duration because they expect to increase profits thanks to the reduction of the production costs. This occurs because productivity increases: In a flexible regime, in fact, the threat of dismissal is consistent and act as a "discipline device", so workers are forced to increase productivity in order to avoid dismissals (Bowles, 1985).

Scholars belonging to the contemporary Italian Post Keynesian tradition (Note 14), however, criticize the flexibility of the labour contract duration under different points of views (see e.g., Forges Davanzati \& Realfonzo, 2000; Realfonzo, 2003, Forges Davanzati \& Realfonzo, 2004, Leon \& Realfonzo, 2008). Pacella $(2005,2008)$, in particular, argues that flexibility of labour contracts produces instable behavioural codes between employers and employees because of uncertainty and asymmetric information. In a flexible regime, it is argued, while the worker cooperates with the employer in order to avoid replacement, the employer can deviate from the implicit agreement replacing workers with the unemployed who are willing to work at low wages. This mechanism however occurs when unemployment is high and workers are highly replaceable. Pacella (2009) then criticizes the validity of the discipline effect in the long run suggesting that the flexibility of the labour contract duration increases productivity only in the short run due to the "LIME (Last In Most Efficient) effect". The rationale is that the newly hired are more productive than those working on expiring contracts because newly hired do not know whether their working relationship will become permanent, as this information is completely lacking or asymmetrically distributed between employers and employees. Moreover, the newly hired are not initially able to gauge the employer's credibility with regards to promises of job security. On the other hand, it is in the employers' interest always to be vague on this point in order to maintain the positive expectations of new workers and thus also their high productivity. At the same time, it is also in their interest to increase personnel turnover in order to take advantage of the high productivity of new employees. As it is not in the employers' interest to provide job security, their promises will come to lose credibility and the newer employees will decrease their efforts and productivity in the same way as the older employees denied permanent contracts. Flexibility thus ultimately causes a decrease in productivity and has a negative impact on economic growth.

Now we show on theoretical plane, and using a very simple model, how flexibility of labour contract can negatively affect productivity, profits and employment and how firms' social responsibility can counterbalance the negative effects of flexibility.

The main hypotheses of the model are: a) firms are price-takers in the consumption goods market (with $p$, the prices), b) households are those of workers and the propensity to consume is equal to one. $c$ ) Firms face an average labour productivity $\pi$ depending on two variables: The level of labour contract flexibility $\alpha$ and firm's social responsibility $\beta$. While the flexibility of labour contracts is measured as inverse of EPL (Note 15), a proxy of firms' social responsibility about the labour force is given by the inverse of the involuntary turnover rate (Note 16). d) There is a range of flexibility that maintains the average productivity over the real wage $w / p$ allowing firms to obtain profits $\Pi$. The real wage, moreover is independent from the flexibility of the labour contract. g) Firms demand labour in the subsequent period according to the expected maximum real profit per worker. For the sake of simplicity the expected maximum real profit is given by the constant $\gamma$ of the current maximum real profits per worker.

In our model firms' social responsibility increases labour productivity because of the operation of the "Hawthorne effect" (see section 2). FSR, in fact, increases firms' reputation and enlarges group identity. Since the state of confidence improves, workers are willing to cooperate more durably among themselves and with employers. At the same time workers are more motivated since they can satisfy several needs such as, and in particular, safety and esteem ones (Note 17). Moreover, in line with Porter and Kramer (2011), FSR improves the creditworthiness of firms and the ability of firms to obtain low costs financing. The new financings firms, in turns, can enlarge capital endowment and increase additionally labour productivity. 
Moreover, an increase of flexibility initially produces an increase of productivity because the credibility of the discipline effect. At the same time productivity increases at decreasing rates until the degree of labour contract flexibility reaches a critical level beyond which productivity decreases because of the operation of "the LIME effect" (Pacella, 2009). This occurs because workers start to undermine reputation and credibility to firms as well as they lose motivation.

Given the above argumentations, indeed, we can depict the average labour productivity as a complex behavioral function depending both on workers and firms' actions and reactions:

$$
\pi=A \alpha^{2}+B \alpha+C \beta
$$

with the constants $\mathrm{A}<0, \mathrm{~B}>0$ and $\mathrm{C}>0 . A$ measures the negative effect of the instability of cooperation on the productivity because of the intensification of flexibility. $B$, instead, is the proxy of the discipline effect and measures the positive effect of cooperation on the productivity. Finally, $C$ measures the positive effect of the FSR on the productivity. Note the productivity function is a parabola with a downward concavity. Given equation [1], the total amount of goods produced by firms is:

$$
Q=\left(A \alpha^{2}+B \alpha+C \beta\right) N
$$

Given then the sales $p Q$ and the production costs $w N$, firms realize the following profits $\Pi$ :

$$
\Pi=\left(A \alpha^{2}+B \alpha+C \beta\right) p N-w N
$$

In real terms the profits [3] becomes:

$$
\frac{\Pi}{p}=\left(A \alpha^{2}+B \alpha+C \beta\right) N-\frac{w}{p} N
$$

Moreover, given equation [4] we can find the following real profit per worker:

$$
\frac{\Pi}{p N}=\left(A \alpha^{2}+B \alpha+C \beta\right)-\frac{w}{p}
$$

Equation [5] states that the higher the productivity the higher the real profit per worker. Let us find now the level of flexibility that allows firms to maximize the real profits per worker:

$$
\mathrm{d}(\Pi / \mathrm{pN}) / \mathrm{d} \alpha=2 \mathrm{~A} \alpha+\mathrm{B}=0 \rightarrow \alpha^{*}=\mathrm{B} / 2 \mathrm{~A}
$$

(Note 18)

Equation [6] states that firms realize the maximum real profit per worker when the flexibility is given by the ratio between the positive effect of cooperation $B$ on the (double) negative effect of the instability of cooperation A.

Given finally the hypothesis f) firms demand labour for the next period according to the following equation:

$$
N^{D}=\gamma\left(A \alpha^{2}+B \alpha+C \beta\right)-\gamma \frac{w}{p}
$$

Substituting the critical level of flexibility [6] into equation [7] the demand, we find the quantity of labour demanded according to the critical level of flexibility:

$$
N^{* D}=\gamma\left[\left(\frac{3 B^{2}}{4 A}+c \beta\right)-\frac{w}{p}\right]
$$

Equations [7] and [8] state that the demand for labour increase when firms' social responsibility increase, so when cooperation tend to become more stable. These effects can be depicted as follows: 


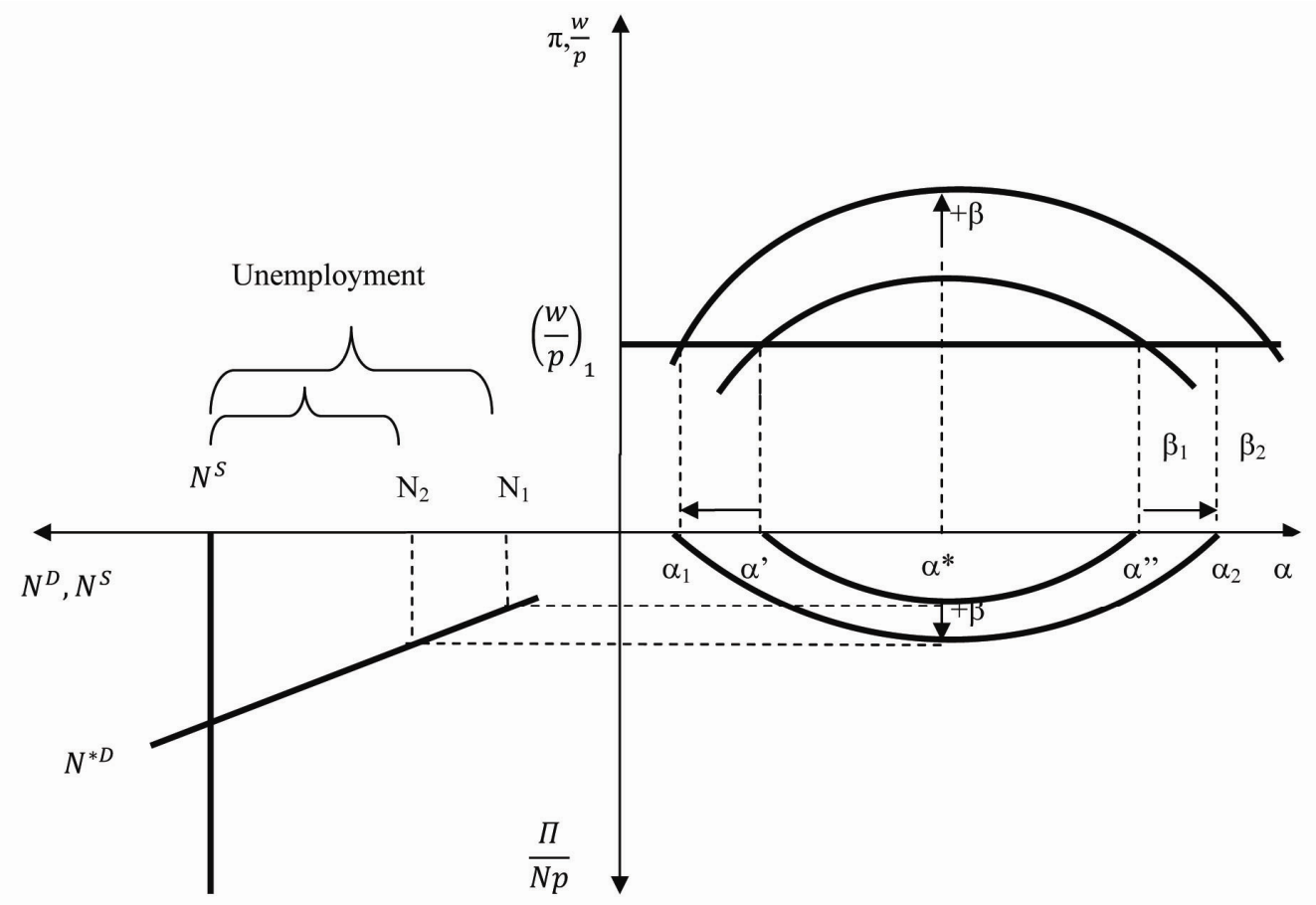

Figure 1 . The effects of flexibility and social responsibility on productivity, profits and employment

The upper right panel portrays the curves of productivity $\pi$ as functions of the flexibility of labour contract $\alpha$ and firm's social responsibility $\beta$ (see equation [1]). As it is possible to note the higher the flexibility the higher the productivity until the same flexibility reaches the critical level (see equation [6]). When the flexibility exceeds the critical one, the productivity starts to decrease. In the same panel we also portray the real wage $w / p$ as a function independent of the labour contract flexibility. Note each productivity curve is depicted for a given level of social responsibility $\beta$. So the lower function depends on the level $\beta_{l}$ while the upper curve depends on the level of social responsibility $\beta_{2}>\beta_{1}$. The distance between the productivity and the real wage measures the real profit per worker and the higher the social responsibility the higher the distance between the productivity and the real wage so the higher the real profit per worker. The points $\alpha$ ' and $\alpha$ " identify the levels of flexibility that produce a nil real profit. An increase of social responsibility, moreover, enlarges the range of flexibility within which real profits are positive (see $\alpha_{1}$ and $\alpha_{2}$ ). This means that the increase of social responsibility enlarges the limit of tolerance of flexibility on the part of workers. The lower right panel portrays, instead, the real profit per worker as projection of the upper right panel. Two profits curves appear in the lower right panel: The first one is closer to the origin of the axes and appears when the social responsibility is fixed at the level $\beta_{l}$. The curve that is instead farther from the origin of the axes is the profit curve when the social responsibility increases reaching the level $\beta_{2}>\beta_{l}$. When the flexibility increases the real profits per worker increase too until the critical level of flexibility is reached. When, instead, the flexibility exceeds the critical level the profits decrease. At the same time the higher the social responsibility the higher the profits. Finally the lower left panel portray the demand for labour $N^{D}$ depicted for each critical level of flexibility and for each level of social responsibility (see equation [8]) and the labour supply $N^{S}$. As it is possible to note employment increases when, ceteris paribus, the firms' social responsibility increases.

\section{Conclusions}

Flexibility of labour markets and firms' social responsibility are generally treated separately in literature. While, however, literature agrees on the opportunity to enlarge the social responsibility of firms it does not agree on the effects of flexibility on the economic performances of firms and workers. This paper has tried to consider jointly the two above mentioned categories in order to show how the social responsibility of firms can counteract some negative effects of the flexibility of labour contracts on productivity, profits and employment. What emerges is that the operation of the "LIME effect" can be counterbalanced by the "Hawthorn effect" when firms are responsible for their own human resources, and that the higher the social responsibility of firms the higher the labour productivity, profits and employment. 


\section{References}

Akerlof, G. A. (1982). Labour contracts as partial gift exchange. Quarterly Journal of Economics, 97(4), 543-569. http://dx.doi.org/10.2307/1885099

Akerlof, G. A. (1984). Gift exchange and efficiency wage theory: four views. American Economic Review, 74(2), 79-83. http://dx.doi.org/10.1017/cbo9780511559594.006

Akerlof, G. A., \& Yellen, J. L. (1986). Efficiency wage models of the labor market. Cambridge: Cambridge University Press. http://dx.doi.org/10.1017/cbo9780511559594

Akerlof, G. A., \& Yellen, J. L. (1987). Rational models of irrational behaviour. American Economic Review, 77(2), 137-142.

Akerlof, G. A., \& Yellen, J. L. (1988). Fairness and unemployment. American Economic Review, 78(2), 44-49.

Akerlof, G. A., \& Yellen, J. L. (1990). The Fair wage-effort hypothesis and unemployment. Quarterly Journal of Economics, May, 255-283. http://dx.doi.org/10.2307/2937787

Alchian, A. A., \& Demsetz, H. (1972). Production, information costs and economic organization. American Economic Review, 62(5), 777-795. http://dx.doi.org/10.1017/cbo9780511817410.015

Almender, R. (1984). The ethics of profits: Reflections on corporate responsibility. In T. R. Swartz \& F. J. Bonello (Eds.), Taking sides: clashing views on controversial economic issues. Guilford, CT: Dushkin Publishing Group Inc. http://dx.doi.org/10.1177/000765038001900201

Argyris, C. (1957). Personality and organization. New Yok: Harper \& Brothers.

Argyris, C., \& Schon, D. (1995). Organizational learning II-Theory, Method and Practice. Addison, Wesley Series on Organization Development. http://dx.doi.org/10.2307/2525281

Axelrod, R. (1984). The evolution of cooperation. New York: Basic Books.

Azariadis, C. (1975). Implicit contracts and underemployment equilibria. Journal of Political Economy, 83(6), 1183-1202. http://dx.doi.org/10.1086/260388

Besser, T. (2002). The Conscience of Capitalism: Business Social Responsibility to Communities. Portsmouth, NH: Greenwood Publishing Group.

Björklund, A., Haveman, R., Hollister, R., \& Holmund, B. (1985). Labour market policy and unemployment insurance. Oxford: Carendon Press.

Boeri, T., \& van Ours, J. (2008). The Economics of Imperfect Labor Market. Princeton: Princeton University Press.

Bordia, P., Hobman, E., Jones, E., Gallois, C., \& Callan, V. J. (2004). Uncertainty during organizational change: types, consequences, and management strategies. Journal of Business and Psychology, 18, 507-532. http://dx.doi.org/10.1023/b:jobu.0000028449.99127.f7

Bowles, S. (1985). The production process in a competitive economy: Walrasian, neo-Hobbesian and Marxian Models. American Economic Review, 75(1), 16-36.

Bowles, S., \& Gintis, H. (2002). Prosocial emotions, Santa Fe Institute, working paper no. 02-07-028 June.

Buchanan, J. M. (1994). Ethics and economic progress. Norman and London: University of Oklahoma Press.

Costabile, L. (1998). Ordine spontaneo o ordine negoziato? In A. Amendola (Ed.), Istituzioni e mercato del lavoro( pp. 1-66). Napoli, Edizioni Scientifiche Italiane.

European Commission. (2001). Libro Verde. Promuovere un quadro europeo per la responsabilità sociale delle imprese. Bruxelles.

Forges Davanzati, G. (2006). Ethical codes and income distribution. A study of John Bates Clark and Thorstein Veblen. London and New York: Routledge.

Forges Davanzati, G., \& Realfonzo, R. (2000). Wages, Labour Productivity and Unemployment in a Model of the Monetary Theory of Production. Économie Appliquée, (4), 117-138.

Forges Davanzati, G., \& Realfonzo, R. (2004). Labour market deregulation and unemployment in a monetary economy. In R. Arena \& N. Salvadori (Eds.), Money, Credit and the Role of the State. Aldershot, Ashgate.

Friedman, M. (1970). The Social Responsibility of Business is to Increase its Profits. The New York Times Magazine, September 13, The New York Times Company. 
Fudenberg, D., \& Levine, D. (1989). Reputation and equilibrium selection in games with a patient player. Econometrica, 57, 759-778. http://dx.doi.org/10.2307/1913771

Gordon, D. F. (1974). A neoclassical theory of Keynesian unemployment. Economic Inquire, 12, 431-449.

Gordon, R. J. (1990). What is New-Keynesian economics? Journal of Economic Literature, 28(3), 1115-1171. http://dx.doi.org/10.4324/9780203443965.ch21

Granovetter, M. (1985). Economic action and social structure: the problem of embeddedness. American Journal of Sociology, 16, 481-510. http://dx.doi.org/10.1002/9780470755679.ch5

Greer, W. B. (2000). Ethics and uncertainty. The economics of John M. Keynes and Frank H. Knight. Cheltenham, Elgar.

Gutmann, A., \& Thompson, D. (1996). Democracy and disagreement. Cambridge: Harvard University Press.

Hogg, M. A., \& Mullin, B. A. (1999). Join groups to reduce uncertainty: subjective uncertainty reduction and group identification. In D. Abrams \& M. A. Hogg (Eds.), Social identification and social cognition (pp. 249-279). Oxford: Blackwell.

Huck, S., \& Kübler, D. (2000). Social pressure, uncertainty, and cooperation. Economics of Governance, 1, 199-212. http://dx.doi.org/10.1007/pl00011015

Hyclak, T., Johnes, G., \& Thornton, R. (2013). Fundamentals of Labor Economics (2nd ed.). Boston: Cengage Learning.

Jahoda, M. (1979). The impact of unemployment in the 1030s and in 1970s. Bulletin of the British Psychological Society, 32, 309-314.

Jahoda, M. (1982). Employment and Unemployment. Cambridge: Cambridge University Press.

Kahneman, D., Knetsch, J., \& Thaler, R. (1986). Fairness as a constraint on profit seeking: entitlements in the market. American Economic Review, 76, 728-741.

Katz, L. F. (1986). Efficiency wage theories: a partial evaluation. NBER Macroeconomic Annual. http://dx.doi.org/10.3386/w1906

Katz, L. F. (1988). Some recent developments in labour economics and their implication for macroeconomics. Journal of Money, Credit and Banking, August.

King, E. (Ed.). (2012). The Elgar Companion to Post Keynesian Economics (2nd ed.). Edward Elgar Publishing.

Kreps, D., \& Wilson, R. (1982). Reputation and imperfect information. Journal of Economic Theory, 27, 257-279. http://dx.doi.org/10.1016/0022-0531(82)90030-8

Lanna N. (2009). Le imprese giapponesi: i pionieri della responsabilità sociale. In M. Siddivò (Ed.), La responsabilità sociale di impresa in Asia. Le nuove sfide per l'internazionalizzazione. Napoli, Unior, Dipartimento di Studi Asiatici.

Lavoie, M. (2014). Post Keynesian Economics. New Foundations. Cheltenham: Edward Elgar Publishing.

Layard, R., \& Nickell, S. (1997). Labour market institutions and economic performance (Working paper n.60), Quaderni CEIS Università degli Studi di Roma "Tor Vergata".

Layard, R., Nickell, S., \& Jackman, R. (1994). The unemployment crisis. Oxford: Oxford University Press.

Leon, P., \& Realfonzo, R. (Eds.). (2008). L'economia della precarietà. Roma, Manifestolibri.

Maslow, A. (1995). Motivation and personality. New York: Harper \& Row.

Mayo, E. (1945). The human problems of an industrial civilization. Boston: Harvard University Press.

McLaughlin, E. (1992). Towards active labour market policies: an overview. In E. McLaughlin (Ed.), Understanding Unemployment: New Prospectives On Active Labour Market Policies. London: Routledge.

Oliva, N. (2015). Management Report Ex. Art. 2428 c.c. in Local Authority Companies. International Business Research, 8(12), 36-50. http://dx.doi.org/105539/ibr.v8n12p36

Pacella, A. (2005). Deregolamentazione del mercato del lavoro, incertezza e occupazione. Economia, Azienda e Sviluppo, 3, 52-65.

Pacella, A. (2008). The Effects of Labour Market Flexibility in the Monetary Theory of Production. Metroeconomica, 59(4), 608-632. http://dx.doi.org/10.1111/j.1467-999x.2008.00330.x 
Pacella, A. (2009). The Effects of Employment Insecurity on Demand, Productivity and Employment Levels. Review of Political Economy, 21(2), 273-289. http://dx.doi.org/10.1080/09538250902834061

Porter, M., \& Kramer, M. (2011). Creating Shared Value. Harvard Business Review, 89(1-2).

Realfonzo, R. (2003). Flessibilità, formazione e salario reale contrattato. Gli indesiderati effetti macroeconomici della deregolamentazione. In R. Realfonzo \& L. Zoppoli (Eds.), Formazione e lavoro: l'efficacia dei nuovi strumenti giuridici e istituzionali (pp. 97-106). Feltrinelli, Milano.

Rees, A. (1973). The economics of work and pay. New York, Harper \& Row.

Ricci, P. (2013). Globalizzazione, irresponsabilità sociale, crisi finanziaria: il corto circuito della società di mercato. In Il Salone della CSR e dell'innovazione sociale Quale futuro per la csr e l'innovazione sociale?

Ricci, P. (Ed.). (2012). L'economia dell'azienda: paradigmi e declinazioni. Milano, Giuffrè.

Rivot, R. (2001). The evolution of the concept of involuntary unemployment: from Keynes to the new Keynesians. History of Economic Ideas, 9(1), 121-144.

Rosen, S. (1985). Implicit Contracts: a survey. Journal of Economic Literature, 23, 1144-1175. http://dx.doi.org/10.3386/w1635

Sacconi, L. (1997). Economia, etica e organizzazione. Bari, Laterza.

Sacconi, L. (2000). The Social Contract of the Firm, Economics, Ethics and Organisation. Springer Verlag, Berlin-Heidelberg.

Saint-Paul, G. (2000). The political economy of labour market institutions. Oxford: Oxford University Press.

Salop, S. C. (1979). A model of the natural rate of unemployment. American Economic Review, 69(1), 117-125. http://dx.doi.org/10.1017/cbo9780511559594.007

Schlict, E. (2002). Social evolution, corporate culture and exploitation. Journal of Institutional and Theoretical Economics, 160(2), 232-242.

Schotter, A. (1986). The evolution of social institutions. In R. Langlois (Ed.), Economics as a process. Cambridge: Cambridge University Press.

Sen, A. (2002). Etica ed economia. Roma-Bari, Laterza.

Shapiro, C., \& Stiglitz, J. E. (1984). Equilibrium unemployment as a worker discipline device. American Economic Review, 74(3), 433-444. http://dx.doi.org/10.1017/cbo9780511559594.004

Shavell, S. (1987). The optimal use of nonmonetary sanctions as a deterrent. American Economic Review, 77, 107-110. http://dx.doi.org/10.2307/1122393

Solow, R. M. (1979). Another possible source of wage stickiness. Journal of Macroeconomics, 1, 79-82. http://dx.doi.org/10.1017/cbo9780511559594.003

Solow, R. M. (1990). The labour market as a social institution. Oxford: Basil Blackwell.

Sudgen, R. (1986). The economics of rights, cooperation and welfare. Oxford: Basil Blackwell.

Sung Ho, K. (2012). Max Weber. In E. N. Zalta (Eds.), The standard encyclopedia of Philosophy. Retrieved from http://plato.stanford.edu/entries/weber/

Taylor, M. (1987). The possibility of cooperation. Cambridge: Cambridge University Press.

Thurow, L. C. (1983). Dangerous currents: the state of economics. New York: Random House.

Van Dun, F. (1994). Hayek and natural law: the Human connection. In J. Birner \& R. van Zijp (Eds.), Hayek, co-ordination and evolution. London and New York: Routledge.

Vanberg, V. (1993). Rational choice, rule-following and institutions: an evolutionary perspective. In U. Maki, B. Gustafsson \& C. Knudsen (Eds.), Rationality, institutions and economic methodology. London: Routledge.

Weber, M. (1918/1919). "Politik als Beruf” in Gesammelte politische Schriften (3rd ed.). Tübingen 1971.

Weiss, A. (1991). Efficiency wages: models of unemployment, layoff and wage dispersion. Oxford: Clarendon Press.

Williams, A. (1993). Human Resource Management and Labour Market Flexibility. Aldershot, Avebury.

Williamson, O. (1985). The Economic Institutions of Capitalism: Firms, Markets, Relational Contracting. New York: Free Press. 
Yellen, J. L. (1984). Efficiency wage models of unemployment. American Economic Review, 74(2), 200-205.

Zamagni, S. (Ed.). (1995). Economics of altruism. Aldershot, Elgar.

\section{Notes}

Note 1. On the perfectly competitive labour market see (among the others) Hyclak et al. (2013).

Note 2. On the imperfections of the labour market see (among the others) Rees (1973), Rosen (1985), Layard, Nickell and Jackman (1994), Rivot (2001) and more recently Boeri and van Ours (2008).

Note 3. For a theoretical and general view of social responsibility of firms in the modern economies, see (among the others) Besser (2002) while for an applied analysis see Oliva (2015).

Note 4. On the nature of cooperation in economics see Schotter (1986), Axelrod (1984), Sudgen (1986) and Taylor (1987).

Note 5. For a critical reconstruction of the nature and effects of moral codes in the economic literature see, among the others, Zamagni (1995), Costabile (1998) and Forges Davanzati (2006).

Note 6. On the rationality of the use of moral rules see, among the others, Vanberg (1993). Others, instead recognize that moral rules mould the behaviour because of the limits of human rationality and the spread of a systemic uncertainty thanks to a sort of innate emotions. On these points see e.g., Buchanan (1994), Huck and Kübler (2000), Hogg and Mullin (1999), Bordia et al. (2004), Greer (2000), Bowles and Gintis (2002).

Note 7. In this respect, Friedman (1970) statement: "Business of business is business" is well known.

Note 8. The ethical codes listed in the Green Book of the European Commission must be based on important international referral points such as the ILO Conventions, the OECD guidelines, the United Natios Global Compact.

Note 9. SA (Social Accountability), CEPAA (Council of Economical Priorities Accreditiation Agency).

Note 10. Self-regulation is intended as a mechanism for which the economic parties join together with the aim to regulate their behaviors in function of particular conduct codes that become binding to the individual's actions. Co-regulation is intended as the co-existence of several tools meant to fix the material content of the rules, determined by the implementation and monitoring procedures. In particular, it is a set of tools allowing different parties to intervene on the firms' behavior, with the purpose to incentivize or obligate them to respect their commitment.

Note 11. http://www.globalcompactnetwork.org

Note 12. Our translation.

Note 13. For a review of the economic approaches to institutions see, among the others, Costabile (1998). On the endogenous nature of institutions see, among the others, Gordon (1974, 1990), Azariadis (1975), Solow (1979, 1990), Salop (1979), Weiss (1991), Akerlof (1982, 1984), Akerlof and Yellen (1986, 1987, 1988, 1990), Yellen (1984), Thurow (1983), Shapiro and Stigliz (1984), Katz (1986, 1988), Alchian and Demsetz (1972), Jahoda (1979, 1982), Williamson (1985), Williams (1993).

Note 14. For a detailed investigation of Post-Keynesian economics see, among others, the recent contributions by King (2012) and Lavoie (2014).

Note 15. The EPL (Employment Protection Legislation) index is furnished by the OECD. It is now the best indicator on the degree of rigidity of the labour market.

Note 16. The involuntary turnover rate is here given by the ratio between the number of involuntary separations and the average number of employees.

Note 17. On the general economic effects of moral norms see, among the others, Granovetter (1985), van Dun (1994), Shavell (1997), Sacconi (1997), Funderberg and Levine (1989), Kahneman, Knetsch and Thaler (1986), Kreps and Wilson (1982) Almender (1984), Schlict (2002).

Note 18. Note $\alpha^{*}$ is a maximum since the second derivate of the real profit per worker is negative because of the negativity of $A$. 


\section{Copyrights}

Copyright for this article is retained by the author(s), with first publication rights granted to the journal.

This is an open-access article distributed under the terms and conditions of the Creative Commons Attribution license (http://creativecommons.org/licenses/by/3.0/). 